
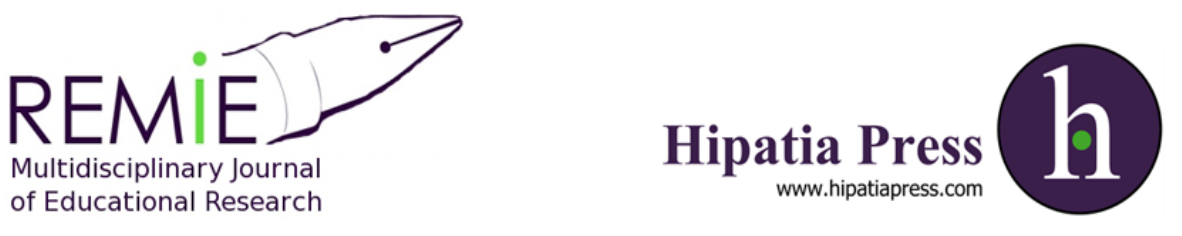

Instructions for authors, subscriptions and further details:

http://remie.hipatiapress.com

\title{
Privileging the Individual Through the Collective Commitment: Parental Strategies and Dynamics of Involvement in a Middle- Class School
}

Javier González-Patiño ${ }^{1}$ \& David Poveda ${ }^{1}$

1) Departamento Interfacultativo de Psicología Evolutiva y de la Educación, Universidad Autónoma de Madrid, España.

Date of publication: October $15^{\text {th }}, 2015$

Edition period: October 2015 - February 2016

To cite this article: González-Patiño, J. \& Poveda, D. (2015). Privileging the Individual Through the Collective Commitment: Parental Strategies and Dynamics Of Involvement in a Middle-Class School. Multidisciplinary Journal of Educational Research, 5(3), 316-336. doi:10.17583/remie.2015.1524

To link this article: http://dx.doi.org/10.17583/remie.2015.1524

\section{PLEASE SCROLL DOWN FOR ARTICLE}

The terms and conditions of use are related to the Open Journal System and to Creative Commons Attribution License (CC-BY). 


\section{Privileging the Individual through the Collective Commitment: Parental Strategies and Dynamics of Involvement in a Middle-Class School}

Javier González-Patiño

Universidad Autónoma de Madrid
David Poveda

Universidad Autónoma de Madrid

\section{Abstract}

This paper attempts to contribute to the growing literature focusing on middle-class parents, their educational strategies and their role in the construction of socioeducational advantages/inequalities especially in the contexts of Spanish educational discourses, to the de-naturalization of middle-class parental ideologies and the educational policies that are presented as ideologically neutral but are closely aligned to this middle-class ideological complex. The findings come from an action research project in a public (state-run) primary school in Spain, attempting to track and document the "natural history" of the various strategies of "school involvement" displayed by parents which range from collaboration with classroom, school and teacher-initiated activities, to surveillance of school policies and programming to open confrontation with the school administration and among parents. This case study uncovers a complex scenario in a relatively homogeneous (in socio-economic and ethnic terms) site where parental dynamics of school involvement are varied and shaped by a complex and heterogeneous set of interests and beliefs that seriously invite to reconsider "school-family continuity" in middle-class settings. Additionally, we would also like to use the case study to raise some ethical and methodological questions in relation to the complexities of holding multiple identities and roles in the field.

Keywords: parental involvement, educational policies, middle-class ideologies, family school relationship, school-family-community 


\section{Privilegiando la Individualidad a través del Compromiso Colectivo: Estrategias ParentalesyDinámicas de Participación en una Escuela de Clase Media}

Javier González-Patiño

Universidad Autónoma de Madrid
David Poveda

Universidad Autónoma de Madrid

\section{Resumen}

Este trabajo intenta contribuir a la creciente literatura centrada en las familias de clase media, sus estrategias educativas y su papel en la construcción de oportunidades y desigualdades socioeducativas, especialmente en el contexto de los discursos educativos españoles, y a la des-naturalización de las ideologías parentales y de las políticas educativas que son presentadas como ideológicamente neutrales y sin embargo se alinean estrechamente con este complejo ideológico de clase media. Los hallazgos proceden de un proyecto de investigación acción en un colegio público de educación infantil y primaria en España, tratando de indagar y documentar la "historia natural" de las diversas estrategias de "participación en la escuela" mostradas por los padres y que van, desde la colaboración en el aula, en el colegio y en actividades promovidas por el profesor, hasta la vigilancia de las políticas y programas escolares abriendo una confrontación con la dirección del colegio y entre las familias. Este estudio de caso revela un escenario complejo en una localización relativamente homogénea (en términos socioeconómicos y étnicos) donde las dinámicas parentales de participación en la escuela son variadas y conformadas por un conjunto heterogéneo y complejo de intereses y creencias que invitan a reconsiderar la "continuidad familia-escuela" en el contexto de la clase media. Además, nos gustaría utilizar el estudio de caso para plantear cuestiones éticas y metodológicas en relación con las complejidades de asumir múltiples identidades y roles en el trabajo de campo.

Palabras clave: participación parental, políticas educativas, ideologías de la clase media, relaciones familia escuela, familia-escuela-comunidad 


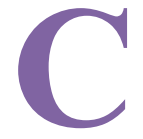

lassic ecological models of human development have stressed the importance of strong connections between school and family micro-systems as a protective factor for children's development and educational trajectories (Bronfenbrenner, 1994). Early anthropological research in the United States examined this interconnection micro-ethnographically, as a question of continuity/discontinuity between the interactional and communicative patterns of children in their families and communities and in school (Cazden, Carrasco, Maldonado-Guzmán, \& Erickson, 1980; Guthrie \& Hall, 1983; Mehan, 1984). Sociological research in Europe, drawing from Bourdieu's general framework (Bourdieu \& Passeron, 2009), re-framed these cultural discontinuities more broadly in terms of symbolic, ideological and cultural overlaps between families and schools as distinct social fields (Lahire, 1998; 2007). Generally speaking, these research traditions have placed their analytic focus on ethnic minority and lower-social class students in an attempt to understand (and ameliorate) historical socioeducational inequalities among students in industrialized democratic educational systems.

In contrast, more recently, within the international research literature there has been a strong interest in understanding school-family dynamics and parental educational strategies within middle-class ('mainstream') families and communities (Nogueira, 2010) - that is, the population segment that has a historically productive relationship with school and comparatively successful socioeducational trajectories. In this latter case, the focus has not been on understanding those processes leading to educational disadvantage but rather on the construction of educational privilege (Lareau, 1987; McGhee Hassrick \& Schneider, 2009) through parental strategies, the structuration of children's activities and involvement in schooling. In relation to previous work this analytical re-focus has also favored two conceptual developments. On one hand, it addresses the critique made to micro-ethnographic work for restricting the analysis of educational inequalities and school-family (dis)continuities to communicative patterns (Ogbu, 1981, 1982). Recent comparative studies focused on families with different socio-economic and cultural characteristics incorporate parental networks, parental and school ideologies, formal and informal spaces of 
collaboration, etc. as elements that fit into the school-family relational equation. On the other hand, they have empirically brought to life -through ethnographically detailed analysis- the notion of "cultural capital" as a structuring force in the constitution of school-family relationships and student's educational trajectories.

A number of research traditions converge in understanding school-family relationships around school as a contributing factor to educational success and as an element which plays a role in the production of socioeducational opportunities and inequalities. Further, the topic is aligned with a practical and policy issue for school administrators, teachers, communities and families focused on establishing and sustaining a productive relationship between the different social actors who play a role in children's education. Western countries with a stronger and more prolonged tradition of public comprehensive and democratically organized education have established practices as to how these dynamics should be addressed -which is not to say these are uncontested or unproblematic. However, in the Spanish case, school-family-community relationships are still contested and unresolved issues (Esteban-Guitart \& Vila, 2013a; Vila \& Casares, 2009). A relatively short history of democratically organized public/state education and changing economic and policy regulations around education complicate establishing a consensus around how teachers and parents, schools and communities should communicate and interact with each other. Also, parents across the socio-economic and cultural spectrum face increasing challenges in the daily management of their relationship and communication with school as work-schedules and the spatial complexities of urban life (Poveda et al., 2007), or linguistic and cultural differences in the case of immigrant and ethnic minority parents (Esteban-Guitart \& Vila, 2013b; Moscoso, 2009), create obstacles to sustain this relationship. In other words, while family-school continuities are consistently construed as a factor that has an impact on children's education and development, in the Spanish case, this move also involves actively constructing, promoting and constraining particular versions of what constitutes parental involvement (Lewis \& Forman, 2002) and of being a "school parent". Further, this construction takes place in a context where the historical precedents of how this relationship is established may be of little practical use. Consequently the investigation of this topic is an especially good occasion to foreground the fact that parents are also educational actors who are transformed during the 
process of their offspring's schooling. In situations where this process is especially intense or involves more change on the part of parents we might even consider it a process where their parental subjectivities are reconfigured (Dyrness, 2009; Jociles \& Charro, 2008; Miller, Hilgendorf, \& DilworthBart, 2014).

\section{Methodology and Research Context}

During the 2011-12 school-year we began a research project focused on the dynamics of parent-teacher collaboration and communication during the preschool years of the Spanish educational system (when children are between 3-6 years of age) over the course of two academic years. The project was framed as an action-based research project in which a shared concern between the teacher in a pre-school classroom and the parents in the class on finding new ways to foster communication between the teacher and parents, increase parental involvement in classroom activities and establishing new forms or collaboration -in a way that was compatible with the time and material constraints that most parents in the class faced- was responded to with the creation of a classroom blog in which the teacher, the students and the parents could participate. This blog was initially created by a parent in the class -the first author of this paper who also ethnographically documented the process- with standard open-access tools and was the catalyst of new forms of parental involvement, children's literacy practices and activities in the classroom. Thus, the project was also conceived to help asses the role that ready-made, open, standard and accessible technological solutions may play in transforming communication between teachers, parents and students and parental involvement in a context where the "ITC aspect" of Spanish education is often seen as having much room for “improvement” (González-Patiño \& Esteban-Guitart, 2014; Sigalés, Mominó, Meneses, \& Badia, 2008) despite the generalized access to internet and technology in Spain (Fundación Telefónica, 2015). Nonetheless, our focus will not be on the affordances of particular technological solutions but rather on the social dynamics that emerge around them to understand the logics of the digital as a way of living and making sense of the world in which we live (Horst \& Miller, 2012) so that research, its theoretical and methodological contributions, could help participants in the process to understand their social reality with the aim of collectively transform it 
(Hurtig \& Dyrness, 2011). The project continued throughout a second year of fieldwork in which both the focus of the study expanded to examine broader school-family dynamics and the researcher-parent "complicated" identities and roles in the project through his involvement in various parental organizational structures of the school.

During the course of fieldwork-intervention-parental involvement a large data-set has been gathered, composed of semistructured interviews and informal conversations with numerous parents, teachers and school administrators, observations and field-notes from various settings where both teachers and parents organize their work, a very large corpus of electronic communications (from the original classroom blog, the school website and numerous electronic discussions among parents) and other paper documents has been gathered. The study also involved participant observation in class meetings and interactions between parents in informal spaces. The larger part of the data collection process (formal and informal observations, documentation and maintenance of the blog and email list, participation in school events, etc.) rested on the first author of the paper in his multirole of school parent, adviser and researcher. Supplementary interviews, analysis of virtual activity and other secondary observations were conducted with the second author of the paper as external researcher to the school site.

The research site for this study is a public school placed in the campus of a large Spanish research-oriented public University located in the outskirts of Madrid - which we will call El Prado (pseudonym). The school serves a primarily middle-class population and is well-known for its commitment to innovative educational practices and strong parental involvement. It caters a relatively socio-economically, culturally and ethnically homogenous population composed almost equally of academic and non-academic employees and students of the University and residents from surrounding areas. This is an institutionally complex school that works with three distinct organizations highly involved in school life: the school parent's association, a different association in charge of after-school support and other programs, and a third organization formed to manage parent's financial contributions to educational activities and materials to provide teachers with resources for teaching and promote equal educational opportunities for children. These three organizations collaborate between them and co-exist alongside the 
school's educational board in which teachers, parents, students and staff are represented.

\section{Results}

\section{Parents' positionings on parental involvement in school}

The institutional complexity of the school we outlined above potentially allows for a range of forms of parental participation and involvement in school life. The data confirm this variability and show how different forms of participation, diverse discourses on the role of parents and parental involvement in the school emerge among the parents we have studied. This variability shows up in a school that apparently has a consolidated and ready-made discourse on family-school relations and parental involvement which is often presented as an emblem of the school. Parents' actual discourses are not incompatible with this "official" representation and often claim to be aligned with it; however, in their practices and representations, we can identify different styles and areas of parental involvement that account for distinct parental positionings and are intertwined with broader socio-educational beliefs.

To organize this variability we propose a model structured along two axis (Figure 1). A first dimension refers to parental involvement styles and is structured along a continuum between involvement/interest in projects/actions which work towards a "common" educational good (collective orientation) and actions oriented to benefit individual members of the community (particularistic orientation). A second dimension refers to the sites through which these parental strategies unfold, which range from the various formally recognized parental organizations of the school (institutionalized sites such as the school board, the school parents association, the parental co-op for school activities or the association for work-family conciliation) to particular initiatives which, more or less explicitly, take place outside these organizations (independent initiatives). These various stand-points have allowed us to identify distinct parental discourses, the various relationships which may exist among the different axis (which might be completely independent intertwine in complex ways) and trace changes over time in the practices of some parents along these dimensions. 


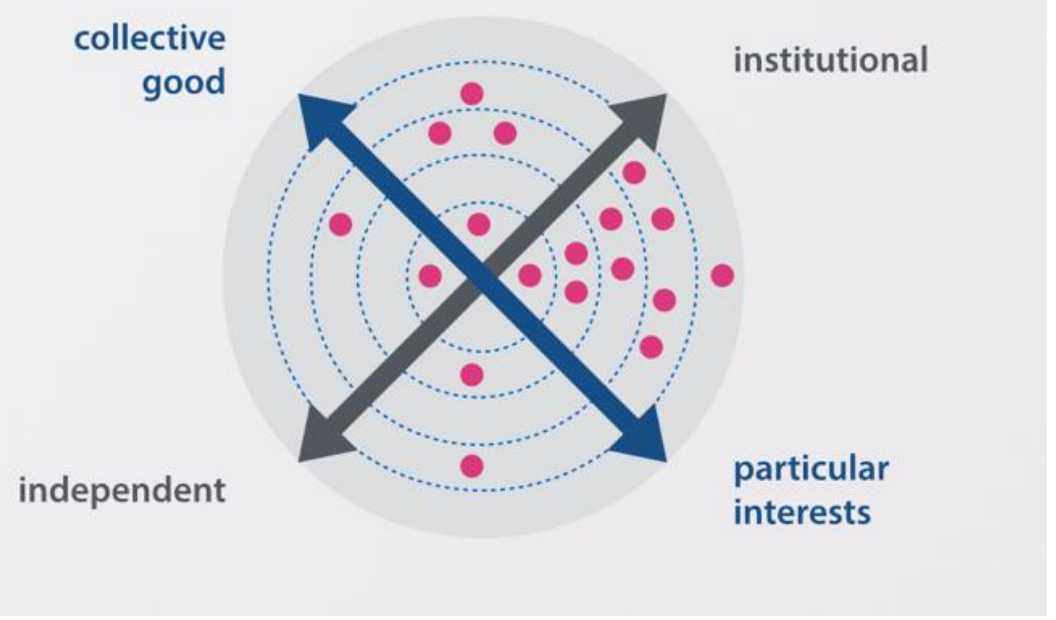

Figure 1. Parental involvement styles and sites.

Parental involvement based on the collective good. In general, families at CEIP El Prado appreciate the added value the school provides as a socialization context in which the different actors that make up the school community are actively involved in school life. As a result, parents who in practice are not too actively involved in school life or are not seen as promoters of parental initiatives, nonetheless, appreciate these dynamics and feel that they can find ways to support them and collaborate with them in various ways. Amalia is a mother in Pablo's class who admittedly describes herself as not one of the "more active parents" in the school but appreciates greatly this aspect of the school and the benefit it provides to the school community:

Extract 1: Interview with Amalia, a mother in Pablo's class (original in Spanish)

The relationship with teachers is different from what is the case in a more common school, if you go and ask parents of other children "do you talk with your teachers?" "Yes, from time to time and so" ... or the relationship among parents in the school, I see that here with our things 


\section{Gonzalez-Patiño \& Poveda-Privileging the Individual}

and all, that we all have a much closer relationship and that we can find ways to meet and we have a different relationship, more like a parentchild team regarding how to work in class that you would find in a regular school.

In contrast, Pilar is emblematic of a parent who is actively engaged in various projects that draw on teacher-parent collaboration. Every year, among other projects, she prepares a book exhibit with Pablo centered on storybooks about emotions which is seen as an important event for students, teachers and parents in the school geared toward the promotion of reading in the early and primary years. She is critical with a participation style among parents in the school which she identifies as limited to financially supporting projects:

\section{Extract 2: Interview with Pilar, mother in Pablo's class}

I miss more "movement" [...] for example, when the end of the school year comes it seems that everything comes down to money, right? money, why? Why can't five or six families get together and prepare and end-of-year school-play instead of taking a trip? [...] So in the end its only four of us, so what? [...] Parents here participate with the computer, giving opinions all the time... and everything we do is "hired" [...] is paid instead of saying "I have a friend, and that I have such..." and this is very good for the kids, because the kids see that, you know, that there is collaboration, cooperation, a participation that is different, different from only putting the money [...] the most wonderful thing is for you to go to the classroom and say, I will tell a story, or I'm going to get together with this parent and we'll do the most fantastic workshop, then it will turn out to be an absolute disaster but we are going to have a ball.

Parental involvement based on particular interests. Until recently Spanish public education was recognizable for its inclusive orientation and apparent espousing of diversity. This discourse emerges with clarity and repeatedly among parents and teachers in the school. Yet, simultaneously and with no apparent awareness of the contradiction (from our perspective) this may involve, some of these parents consider it an advantage for the education of their children that there is little diversity among families in the school and that they are privileged in the sense of being able to mobilize a 
great number of resources to improve the educational experiences and achievement of their children:

\begin{abstract}
Extract 3: Interview with Raul and Amalia, parents Pablo's class
Raul: With other schools it can be shocking, oh well, maybe it's a bit ugly to say so and this is being recorded... there is a selection without... a selection without, how could I explain it without sounding horrible?

Amalia: Well, that the environments is a little more controlled, the environment and we know very well what we will find.

Raul: We all agree, for example I have many colleagues who, who have children in El Prado and we all agree that it's a bargain deal, right? to have a school like this, well a school, a public school, its shocking, also the environment...
\end{abstract}

Raul and Amalia work as administrative staff at the university campus where the school is located; their discourse overlaps with the ideologies of other middle-class families in the school and also with the beliefs of other parents who, as academics, can be considered as members of the cultural elite of the school:

\title{
Extract 4: Interview with David and Alicia, parents in Pablo's class
}

David: Parents at this school are all one level, well there is a group in this school who are highly educated, are university professors, then that has its consequences some are also bad, they are very civilized and very educated and know many things, when we have workshops or whatever, when preparing a science workshop, people immediately show up, immediately provided resources and such, but then they are also very... very "smart", then most people think they know more than the teachers, especially in their respective disciplines, they start: "and you told them such a thing ... and that's not how it's done... you told them this and actually it's this other way..." [...] Then there is a group of [university] teachers, clearly our friends are more or less of this group, but then there is another group of parents who work in other professions. What there isn't, and with this I finish (...) compared to other schools there, there is almost no immigration, no children who are not fluent in the language, which is a problem in other schools. 
A series of conditions, which are construed as happenstance by parents, in the school create a privileged environment in which many of the "problems" (as defined by parents) which are portrayed as frequent in Madrid public education are avoided at CIEP El Prado. From the perspective of these parents this has a favorable effect on their children's education. Additionally, parents in the school sometimes propose projects that favor certain children, forming advocacy groups for particular causes even if this means engaging in confrontations with teachers or the school administration. Yuri, a mother who is highly involved in this educational community, led an effort, alongside other parents with whom she maintained a close friendship, demanding from the school principal and teacher staff the development of a special needs program for her child (i.e. the creation a special class for children with severe developmental disorders) which would involve rewriting the school's educational project. Even though this claim did not prosper they did get some financial support from parents, since they did manage to have the parental co-op for school activities approve and provide funding to hire a support professional for the child during recess time at school:

\section{Extract 5: E-mail sent by Yuri to a board member of the parental co-op}

$[\ldots]$ there are some things that do not add up and I think [...] someone is giving incorrect information (to put it kindly) [...] It seems to me that the principal is not doing her homework, delaying without justification the action [...] I cannot begin to tell you how upset some parents who have approached me personally are [...] Anyway, as a member of the parental co-op board, I beg you to mediate and pressure to unblock this initiative [...] Confident in the relationship I think we have I hope my request will not bother you $[\ldots]$

Forms of institutional participation. Regardless of the involvement sly along the dimensions we have just discussed, family participation is managed either through the parental organizations present in the school, as a personal initiative or as a combination of both to varying degrees. As explained above, all these parental organizations are either regulated by general Spanish educational legislation or have governing statutes that stress democratic forms of representation and participation. In combination they offer families a complex associative structure that is practically endorsed by 
all parents, although as Alicia, a board member of the parental association, recalls with various degrees of active engagement:

\section{Extract 6: Interview with Alicia, mother of Pablo's class}

(Families) don't go to parental association meetings and they will not go to co-op meetings if they are about routine matters, say, unless there ... but yes, yes ... yes they demand to know what is happening, that although there are many parents ... [ ...] not involved physically in meetings there, because I do it, the parental association board meets almost every two weeks, people don't go to these, right? And general assemblies because I know, somewhere, maybe there are 20 parents... $98 \%$ of parents are part of the parental association and I think all belong to the co-op... then ... but they do participate in the website, send emails to the general list, or they make suggestions, if there are problems with teachers or a general problem in a class, then they go to the parental association, so the parental association can talk to the school administration, so they are not physically present but they are there.

Sites of independent participation. In a school with a high predisposition to joint participation between parents and teachers, it would not be surprising to document other collaborative practices outside the institutional frameworks we have just discussed. Pilar (Extract 2) would be such a case, in which families and teachers find a personal level to develop and promote initiatives aimed at the community as a whole or to target small groups or individuals. One morning, after dropping off their children Javier approached Pilar, interested in knowing more about the initiative to encourage reading she was launching with Pablo, their children's class teacher:

Extract 7: Field-notes from the conversation between Javier and Pilar

As president of the parental co-op I remind her that this association could help organize the event since it was an activity that is offered to the entire educational community. To this she replied that she did not feel comfortable working with the associations of school, she worked with people she trusted and was was wary that parental associations or other institutions could sometimes distort the meaning of school activities. 
Complexities in forms of parental involvement and participation. We have proposed the model and the categories we have discussed so far to attempt to uncover and examine the diversity in parental discourses and practices that exists in this school. We have selected relatively clear-cut exemplars of each of the extreme values in the model we have proposed and advanced above that each of these axis could (or not) interrelate in various ways. Yet, parental strategies can also be much more complex, simultaneously mobilizing various of the elements we have discussed so far and even changing over time. For example, seeking the individual support and involvement of other parents or teachers for particular interests may emerge as a complementary strategy to the parental institutional actions to pressure school management. At the time of the interview Yuri (Extract 6 and below) had unsuccessfully run for election as a parent representative in the school board. A year later, when her children were in primary education, she was successful in being elected to a seat in the school board but this new institutional position did not seem to affect her strategy of mobilizing particular parents and some teachers in favor of the special needs resources for her child which she had outlined a year before:

\section{Extract 8: Interview with Yuri, mother in Pablo's class}

I've found my means, say in a particular group of parents, where we have an understanding and we find our outlets... but I am very surprised that there has not been a debate, say a formal debate... through formal channels [...] I think this gives an idea of, first, of what we want from our school and, second, to make ourselves visible.

Further, parents positions in the school change over time, which affects their participation, forms of involvement and discourses. The case we have just discussed is one example of this transformation as Yuri assumed different roles in the school through time. Javier, the first author of this paper and field-worker of the project is another emblematic example. He started the classroom blog project as an independent initiative for his daughter's classroom and the following school-year began assuming important responsibilities in the parental co-op when he led a group of parents to be elected for the managing board of the co-op. Finally, the emergence of virtual sites for parent-teacher collaboration and other digitally 
mediated forms of interaction also transform (and even disrupt) these practices and ideologies. As this virtual contexts is at the center of the research project, we examine its place and impact more specifically.

\section{Virtual Spaces and New Forms of Parental Participation and Interaction}

The model and findings show the different degrees of active participation, styles and areas of involvement that can be found among parents in the school. Some families may legitimize their role in setting the terms of the relationship between teachers and parents, others may seek educational improvements in the classroom for the benefit of their children, others have a predisposition to cooperate and have high expectations in relation to the possibilities and practices of the school, yet others seem to construe the school in terms that go beyond what is usually the discourse of middle-class families and reproduce ideologies more typical of socio-economic and cultural elites (see below). This study developed out of an action-research project that set out to explore new forms of communication and family involvement in the classroom through social web tools. The results suggest that this "expanded" virtual space developed as an open and inclusive experience which allowed parents, especially those outside mainstream school practices or who did not cooperate regularly in class activities or with the school, to access and interact with the teacher in new ways, transforming their relationship and creating new participation practices that have positive effects on some families. For example, Dora (a classroom mother who works as administrative staff in the campus) before the creation of the blog only resorted to more formal or regulated mechanisms of communication such as teacher-parent conferences or the quarterly wholeclass parent meetings:

\section{Extract 9: Interview with Dora, mother in Pablo's class}

Interviewer: What kind of participation do you usually have in the blog? [...]

Dora: We really, it is usually passive, read, read what's there and then yes, what we do is work with what we read, this we do, then if the teacher posts something [...] when my husband arrives "shh, they've 
written in the blog", then at home I take the computer, I open the blog: "dinosaurs" and from that we get to work, we prepare documentation, prepare photos, prepare such and such.

Nonetheless, the activity deployed by Pablo over the two school years the blog was active transformed parental involvement practices in more formal spaces (such as the quarterly class meetings). It also profoundly changed the relationship with families, even those that had an active access to the school and fluid daily contact, such as Yuri (Extract 5) and Alicia (Extract 6):

\begin{abstract}
Extract 10: Interview with Yuri, mother in Pablo's class
I discovered Pablo absolutely committed to education, quite involved with the children, with families, with interesting ideas, imaginative, creative, and I discovered a different teacher, different from what I thought he was. [...] I sincerely believe that if Pablo had not made the blog, I would have missed this Pablo, I would not have wanted to miss this.
\end{abstract}

\title{
Extract 11: Interview with Alicia, mother in Pablo's class
}

Since Pablo participates a lot in the blog and tells about what he's doing, so that parents... which they like, and somehow ... he has brought us closer, right? because Pablo's posts seem to me very loving, that is, they are like very natural, you really imagine the children sitting in a circle and what they are doing, right? I think it brings everything closer, and if a teacher is a bit more shy or is newer, it may somehow make you participate in class without actually invading it.

More interestingly, the introduction of a new digital space of communication has another effect for certain profile of families. Families with more links to the school, who belong to dominant parental institutions and/or participate intensely in school matters also somehow indicate that family-school relations are transformed in a digitally mediated scenario. They are not so easily controlled, it is more difficult to produce a "unified" voice and participation is more diverse and plural:

\section{Extract 12: Interview with Yuri, mother in Pablo's class}

(In relation to participation in the classroom blog) The only thing I regret is not having had a little more time to be more on top of things, 
I always followed it, and I worked on some things more than others, but since I'm a little angry with the school, I'm also doing a bit there ... well, I'm not doing my homework as I would like to [...] The blog is a great non-intrusive source of information [...] It's a tool that I would love that the children could continue having.

\section{Extract 13: Interview with Alicia, mother in Pablo's class}

(On the uses parents make of the blog) We're not using it ... I mean we're not exploiting it as much as we could.

In short, digital practices promote an interactive transformation of spaces, such as a mutual inclusion between home and school - when adults allow this to occur (González-Patiño, 2011; González-Patiño \& Esteban-Guitart, 2015). In a highly regulated formal context laden with ideological conflicts such as schools, digital relations seems to disrupt conventional practices and the delicate power balances between/among parents and teachers.

\section{Conclusions}

\section{The Parental Construction of Educational Advantages in a Public School}

The attempt to understand and situate the processes of parental involvement of a number of middle class families in a public school with such a strong reputation and historical tradition of parental participation and defense of public education as El Prado, has, in fact, led us to critically re-assessment of some common ideas (especially in Spanish policy and research literature) on the role of family-school relationships as a key factor contributing to educational success. More so, we raises questions when this factor is couched within an educationally inclusive discourse which is espoused by a good majority of parents who act in defense of public education and is taken as a central identity trait of Spanish public schooling. In fact, families when they can, produce educational privileges and opportunities for their children that could not be enjoyed or are not accessible to the most vulnerable families or those at risk of social exclusion in the Spanish educational system. In other words, the school emerges as a site of distinction and advancement for the "fortunate" students who attend CEIP El Prado 


\begin{abstract}
Extract 14: Interview with Yuri, mother of Pablo's class
Since we have no other deficiencies were, because we can afford it by, say, because of the type of families who go to this school, because of the type of children... because of the privileged environment it moves in, I think we could make an effort in some things for which we have special conditions, right? such as the study of languages, foreign languages, or for example, attention to diversity, I mean, we have no cultural integration problems, no problems with broken or marginal families.
\end{abstract}

And it is worth point out here how the concept of "diversity" was used by the group of families who staged the confrontation with the school administration and teachers demanding a classroom to care for a child with a severe developmental disorder. Supported by a certain consensus and the absence of opposition from other members of the educational community, their "diversity" proposal excluded any measure or adaptation that was not related to meeting the needs of children with developmental disorders. For example, it did not take into account other notions of diversity such as those emanating from cultural or socio-economic factors. More so, even though the school has some foreign-origin families (mainly from South America and Asia), these families come to the school assuming an assimilationist ideology that antagonizes with anything related to intercultural education or more respectful of differences and funds of knowledge children might bring to the school. Jesus came to Spain a little over four years ago while completing his $\mathrm{PhD}$ and is now a university professor in Madrid. He is explicit of what he valued and why he chose this school for his child despite the fact that he now works at another university away from the campus where the school is located:

\title{
Extract 15: Interview with Jesus, a father in Pablo's class
}

It may sound strange but let's say, I seek the least diverse institution as possible, an institution for example when I was looking at schools in Leganés [a city in the southern metropolitan area of Madrid]...okay? they are very varied, culturally are varied, are very rich right? yet the teaching process, the learning process becomes everything becomes more demanding right? and what I wanted or what I intend it to be a pro ... what matters is the educational process... not just surviving the... the arbitrariness of the world and all this [...] after all, I admit I 
am the oddity, because I recognize, in this country we are the oddity, right? we are foreigners... we are doctors... work in a university... well, how many foreigners are doctors, enter university right? We can count them with our hands, right? Then I have very different expectations, I sometimes feel that people do not know how to treat me, they see me as a foreigner, right? but not like other foreigners... here I feel like any other person.

While families in the school openly and actively support a discourse of integration, equal opportunity and respect for diversity as pillars of public education (i.e. the parental association of the school exhibited permanently in the center a banner in defense of public education), we find that, in practice, some socio-educational ideologies in the school are built around different criteria: "selection" (homogeneity of the families) and "use of the privileges" of the environment. These criteria contribute to generate educational inequalities among students within the public education system of Madrid that, from our perspective raise paradoxes and contradictions that parents at CEIP El Prado did not seem aware of or willing to address. In fact, the first author, as member of the management board of the parental co-op for school activities, had access to financial practices, formal and informal arrangements (that are even difficult to disclose or witness by other parents in the school) that, in effect, allowed parents to financially support students and the school in ways that very much emulate the financial practices of Spanish "private subsidized" schools (centros concertados) - the nemesis often singled out by defendants of public education in Madrid.

\section{References}

Bourdieu, P. (1994). Raisons pratiques: Sur la théorie de l'action. Paris: Éditions du Seuil.

Bronfenbrenner, U. (1994). Ecological models of human development. In T. Husten \& T.N. Postlethewaite (Eds.), International encyclopedia of education (2nd edition) (pp. 1643-1647). New York: Elsevier.

Cazden, C., Carrasco, R., Maldonado-Guzmán, A., \& Erickson, F. (1980). The contribution of ethnographic research to bicultural bilingual education. In J. Alatis (Eds.), Georgetown University roundtable on 
334 Gonzalez-Patiño \& Poveda-Privileging the Individual

languages and linguistics 1980 (pp. 65-80). Washington: Georgetown University Press.

Dyrness, A. (2009). Cultural Exclusion and Critique in the Era of Good Intentions: Using Participatory Research to Transform Parent Roles in Urban School Reform. Social Justice, 36(4(118)), 36-53. Retrieved from http://www.socialjusticejournal.org/?product=andrea-dyrness-2 Esteban-Guitart, M., \& Vila, I. (2013a). Experiencias en educación inclusiva: Vinculación escuela, familia y comunidad. Barcelona: Horsori.

Esteban-Guitart, M., \& Vila, I.. (2013b). La modificación de las creencias sobre las familias de origen inmigrante por parte de docentes después de participar en el proyecto educativo "fondos de conocimiento". Cultura y Educación, 25(2), 241-254. doi:10.1174/113564013806631282

Fundación Telefónica. (2015). La sociedad de la información en España 2014. Barcelona: Ariel.

González-Patiño, J. (2011). Rutinas de la infancia urbana mediadas por la tecnología: Un análisis visual. Papeles de Trabajo sobre Cultura, Educación y Desarrollo Humano, 7(2), 1-16. Retrieved from http://www.uam.es/otros/ptcedh/2011v7_pdf/v7n2esp.pdf

González-Patiño, J., \& Esteban-Guitart, M. (2014). Some of the challenges and experiences of formal education in a Mobile-Centric Society (MCS). Digital Education Review, 25, 64-86. Retrieved from http://revistes.ub.edu/index.php/der/article/view/11329

González-Patiño, J., \& Esteban-Guitart, M. (2015). Fondos digitales de conocimiento e identidad: Un análisis etnográfico y visual. Papeles de Trabajo sobre Cultura, Educación y Desarrollo Humano, 11(2), 2025. Retrieved from

http://www.uam.es/otros/ptcedh/2015v11_pdf/v11n2sp.pdf

Guthrie, L., \& Hall, W. (1983). Continuity/discontinuity in the function of language use. Review of Research in Education, 10, 55-77. doi:10.3102/0091732X010001055

Horst, H. A., \& Miller, D. (2012). Digital anthropology. London, New York: Berg.

Hurtig, J., \& Dyrness, A. (2011). Parents as Critical Educators and Ethnographers of Schooling. In B. A. U. Levinson \& M. Pollock 
(Eds.), A Companion to the Anthropology of Education (pp. 530-546). Oxford, UK: Wiley-Blackwell.

Jociles, M., \& Charro, C. (2008). Construcción de los roles paternos en los procesos de adopción internacional: El papel de las instituciones intermediarias. Política y Sociedad, 45(2), 105-130. Retrieved from http://revistas.ucm.es/cps/11308001/articulos/POSO0808230105A.PD $\mathrm{F}$

Lahire, B. (1998). L'homme pluriel: Les resorts de L'action. Paris: Nathan. Lahire, B. (2007). Infancia y adolescencia: De los tiempos de socialización sometidos a constricciones múltiples. Revista de Antropología Social, 16, 21-38. Retrieved from

http://revistas.ucm.es/index.php/RASO/article/download/RASO07071 $10021 \mathrm{~A} / 9115$

Lareau, A. (1987). Social class differences in family-school relationships:

The importance of cultural capital. Sociology of Education, 60(2), 7385. doi:10.2307/2112583

Lewis, A., \& Forman, T. (2002). Contestation or collaboration?: A comparative study of home-school relations. Anthropology and Education Quarterly, 33(1), 60-89. doi:10.1525/aeq.2002.33.1.60

McGhee Hassrick, E., \& Schneider, B. (2009). Parent surveillance in schools: A question of social class. American Journal of Education, 115 (2), 195-225.

Mehan, H. (1984). Language and schooling. Sociology of Education, 57, 174-183. doi:10.2307/2112601

Miller, K., Hilgendorf, A., \& Dilworth-Bart, J. (2014). Cultural Capital and Home-School Connections in Early Childhood. Contemporary Issues in Early Childhood, 15(4), 329-345. doi:10.2304/ciec.2014.15.4.329

Moscoso, M. (2009). Perspectivas de padres y madres ecuatorianos sobre el contrato pedagógico entre la institución escolar y la familia en un contexto migratorio. Papeles de Trabajo sobre Cultura, Educación y Desarrollo Humano, 5(1), 1-40. Retrieved from https://www.uam.es/otros/ptcedh/2009v5_pdf/v5n1esp.pdf

Nogueira, M. (2010). Classes médias e escola: Novas perspectivas de análise. Currículo sem Fronteiras, 10(1), 213-231. Retrieved from http://www.curriculosemfronteiras.org/vol10iss 1 articles/nogueira.pdf 
336 Gonzalez-Patiño \& Poveda-Privileging the Individual

Ogbu, J. (1981). School ethnography: A multilevel approach. Anthropology and Education Quarterly, 12(1), 3-29. doi:10.1525/aeq.1981.12.1.05x1281g

Ogbu, J. (1982). Cultural discontinuities and schooling. Anthropology and Education Quarterly, 13, 290-307. doi:10.1525/aeq.1982.13.4.05x1505w

Poveda, D., Casla, M., Messina, C., Morgade, M., Rujas, I., \& Cuevas, I. (2007). The after school routines of literature-devoted urban children. Children's Geographies, 5(4), 423-441. doi:10.1080/14733280701631890

Sigalés, C., Mominó, J. M., Meneses, J., \& Badia, A. (2008). La integración de internet en la educación escolar española: Situación actual y perspectivas de futuro. Informe de investigación. Barcelona: Fundación Telefónica / Universitat Oberta de Catalunya / Internet Interdisciplinary Institute (IN3).

Vila, I., \& Casares, R. (2009). Educación y sociedad: Una perspectiva sobre las relaciones entre la escuela y el entorno social. Barcelona: Horsori.

Javier González-Patiño is researcher at Universidad Autónoma de Madrid and founder at Mediática.

David Poveda is Associate Professor at Universidad Autónoma de Madrid.

Contact Address: Javier González-Patiño Mediática

C/ Bustamante 18

28045 Madrid

Email: javier@mediatica.co / javier.gonzalezpatino@uam.es 